\title{
Waitaki: Water of Tears, River of Mana
}

This paper illuminates the significance of the braided mighty Waitaki River and how it sustains the people that shelter within her valley. This article begins acknowledging Rākaihautū as the first person to occupy and consecrate the land of Te Waipounamu, the South Island of Aotearoa New Zealand. It is Rākaihautū that journeyed through this island as he carved out and named the great southern mountains and lakes, thus establishing ahi kā (occupation rights) of the Waitaha tribe. These ancient names anoint and link these sacred waterways and bountiful pools to the ancestral Pacific homelands of Te Patu Nui o Aio. The naming and formation of the land and cascading waterways that flow from her is further explored in a pūrākau (narrative) about the Māori atua (deity) of Tane and his brothers, which includes the positioning of his tallest brother Aoraki, whose tears symbolically represent the Waitaki River.

The second half of this article then turns to focus on several Waitaha sociocultural and political events based around the Waitaki River and valley over the last one hundred and fifty years. One of the major founding political and cultural events within the Waitaki Valley includes the passive resistance march of Te Heke (1877-79), led by Te Maihāroa, in protest against settler land encroachment and Māori grievances against the Crown. ${ }^{1}$ The concluding segment highlights contemporary political struggles and cultural events along the banks of the Waitaki River, such as the Ocean to Alps (1990) commemorations, celebrating 150 years since the signing of Te Tiriti o Waitangi (Treaty of Waitangi) and Te Heke Ōmāramataka (2012), which was a peace march to honour the mauri (spirit) of the Waitaki river. The Waitaki River is also a site of political and environmental struggles, as highlighted by two Waitaha environmental submissions aimed to protect the Waitaki river against Meridian Energy's hydro projects: Project Aqua (2001-2004) and the North Bank Tunnel (2005-2009).

These events reflect the sacredness of the ancestral Waitaki River to the Waitaha People, a river that has mana (prestige) and is a river of tears. The title of this article is derived from a New Zealand Geographic article called Waitaki: Water of Tears, River of Power. ${ }^{2}$ It stems from the writer's PhD thesis, ${ }^{3}$ which is based on Waitahataka (being Waitaha), of which the Waitaki River remains the bloodline and veins of the Waitaha people. The second half of this article draws on material from the writer's PhD interviews with kaumātua Rangimārie Te Maihāroa and Anne Te Maihāroa Dodds, and from whānau journals, and is woven together with an Indigenous autoethnographic thread: 
Ko au te Waitaki, ko Waitaki ko au.

I am the Waitaki and the Waitaki is me.

\section{The Water Pools of Rākaihautū}

Wāhia te awa e uta ki tua

Puta I waho ko te pākiaka o te rākau

O Māere nuku, o māere raki

O māere I te maro-whenua

I ruka tāne, I raro tāne

Pākupāku tāne, rakaihi tāne

Nohaka nō Te Ariki

Hoatu au, e tāne ki uta! ${ }^{4}$

This ancient karakia (incantation) was recited by Rākaihautū, the famous kaihautū (navigator) of Te Uruao Kapuaraki, the Waitaha ancestral waka (canoe) that first landed at the northern bay of Wakatū (Nelson) in Te Waipounamu, the South Island of Aotearoa New Zealand. This powerful karakia was invoked to create a divide with Te Moana Nui a Kiwa (Pacific Ocean), thus creating a channel and safe passage for his people. Rākaihautū sailed Te Uruao from their ancestral Pacific homelands of Te Patu Nui o Aio, near Hawaiki, landing waka at Wakatū around 850 AD. Through this first sighting and discovery of new land, Rākaihautū is accredited with establishing te take whenua kite (the ancestral occupation rights) of the Waitaha tribe.

Rākaihautū was accompanied by his wife, Te Waiariki o Aio, their son Rakihouia (also recorded as Rokohouia), and the Waitaha people. Rākaihautū and Rakihouia were the ariki (leaders and guardians) of their people, directing two journeys of discovery, where Rākaihautū led one group that explored and named the whenua, and Rakihouia guided the other group down the east coast of Te Waipounamu, sailing through Raukawa Moana (Cook Strait), over Tai o Marokura (passage of ocean past Kaikōura) to Waihao, at the mouth of the Waitaki River, where both parties met up again.

Rākaihautū traversed south through the ngāhere (forests) with his magical ko (wooden spade) named Tū Whakarōria, dug the first water channel and formed the two lakes Rotoroa and Rotoiti. He then led his people south, creating and naming the great Te Waka o Aoraki (the Canoe of Aoraki) and carved out Te Karikari o Rākaihautū, the interior southern lakes along the spine of the South Island (see the telling of the place names of the ancestors in the story at "Place Names from Rākaihautū's Journey"). ${ }^{5}$ Rākaihautū is the founding tīpuna that lit the first fires of human occupation from Raukawa Moana (Cook Strait) to Te Ara a Kewa (Foveaux Strait) and up to Banks Peninsula, thus establishing mana whenua for Waitaha, as described in the following whakataukī (proverb):

Ko Rākaihautū te takata nānā I tīmata te ahi ki ruka i te whenua. Koia koraparapa, koia te kaihautū, koia te takata. He tipua he taniwha, he tipua he takata. Ko Rākaihautū te takata nana i timata te ahi ki ruka ki tēnei motu ka nohoia tēnei motu e Waitaha.

(Rākaihautū was the man that lit the fires of occupation of this island for Waitaha). 
Rakihouia sailed Te Uruao south to Waihao, near the mouth of the Waitaki River, where he reunited with Rākaihautū. Their ancient journeys are remembered because they consecrated and named the whenua, as recorded in A Tale from He Korero Pūrākau Mo Ngā Taunahanahatanga a Ngā Tūpuna, Place Names Of The Ancestors - A Māori Oral History Atlas. ${ }^{6}$ Looking for tohu (signs) and guidance from the atua, Rākaihautū anointed the whenua, and offered his prophetic declaration of what gifts this whenua held for this people. Arriving from a Pacific island to a very different southern climate and landscape, Rākaihautū invested his knowledge and cast his intentions of prosperity and bountifulness for his people. Water is, and remains, a fundamental element to enable life to continue and flourish. For Waitaha, the water pools that Rākaihautū created with his ko are culturally significant in recognition of the creation of these lifegiving landscapes and the ability to remain kaitiaki for these exploratory indigenous sites. The significance of this auspicious occasion is depicted in an artwork by Brian Flintoff and the following whakataukī (proverb):

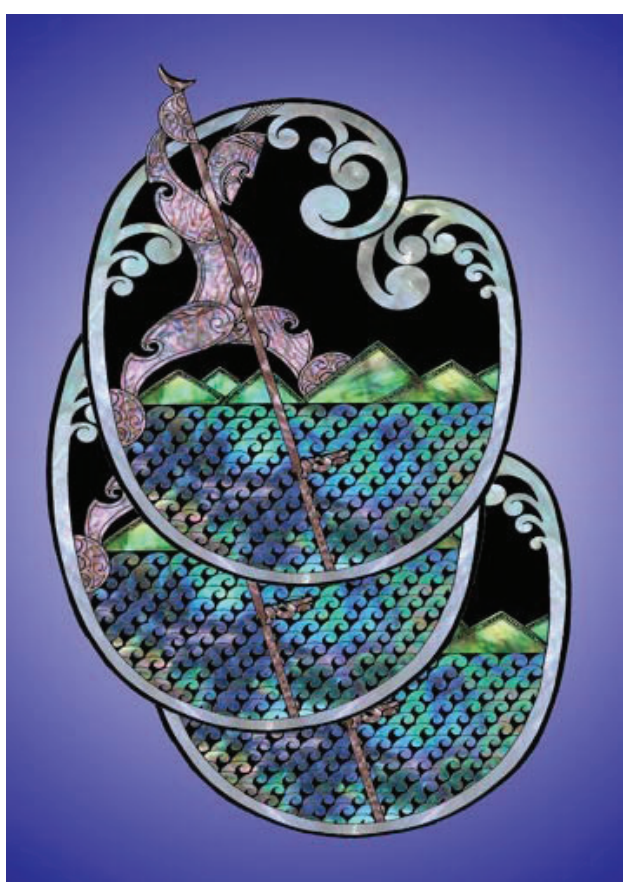

Figure 1. Brian Flintoff, Rākaihautū, mixed media. Brian Flintoff's work depicts Rākaihautū digging out the mountain lakes as he travels through the Southern Alps. Private Collection.

He Puna Waimarie, Te Puna Hauaitu, Te Puna Karikari

The pools of frozen water, the pools of bounty, the pools dug by Rākaihautu

(Te Kete Ako a Rākaihautu)

\section{THE WAITAKI RIVER: A RIVER OF TEARS}

As direct descendants of Rākaihautū and Te Waiariki o Aio, my people have a responsibility to uphold the delicate symbiotic balance between our people and Papatūānuku Earth Mother. Waitaha hold a spiritual covenant to uphold our ancient tikaka to sustain the mauri of our ancestral awa and waterways, expressed as a customary interest, as kaitiaki caretakers and protectors of her divine essence. The great southern Waitaki River is of paramount importance to Waitaha as it is sourced from Aoraki, our mauka teitei (highest mountain) in the Southern Alps. The Waitaki River was given the name wai (water) and taki or tangi (weeping sound). ${ }^{7}$ The prominence of Aoraki reminds us of the courageous deeds of Tāne Mahuta and his demigod brothers, including Aoraki. When their fishing excursion turned treacherous, their waka was tipped upside down, and the brothers were immortalised in stone. Aoraki, being the tallest and eldest brother, become our tippuna mauka (ancestral mountain), the source of the scared Waitaki river. The braided river channels of the Waitaki river symbolically represent the tears shed by Tāne, flowing down throughout the Waitaki 


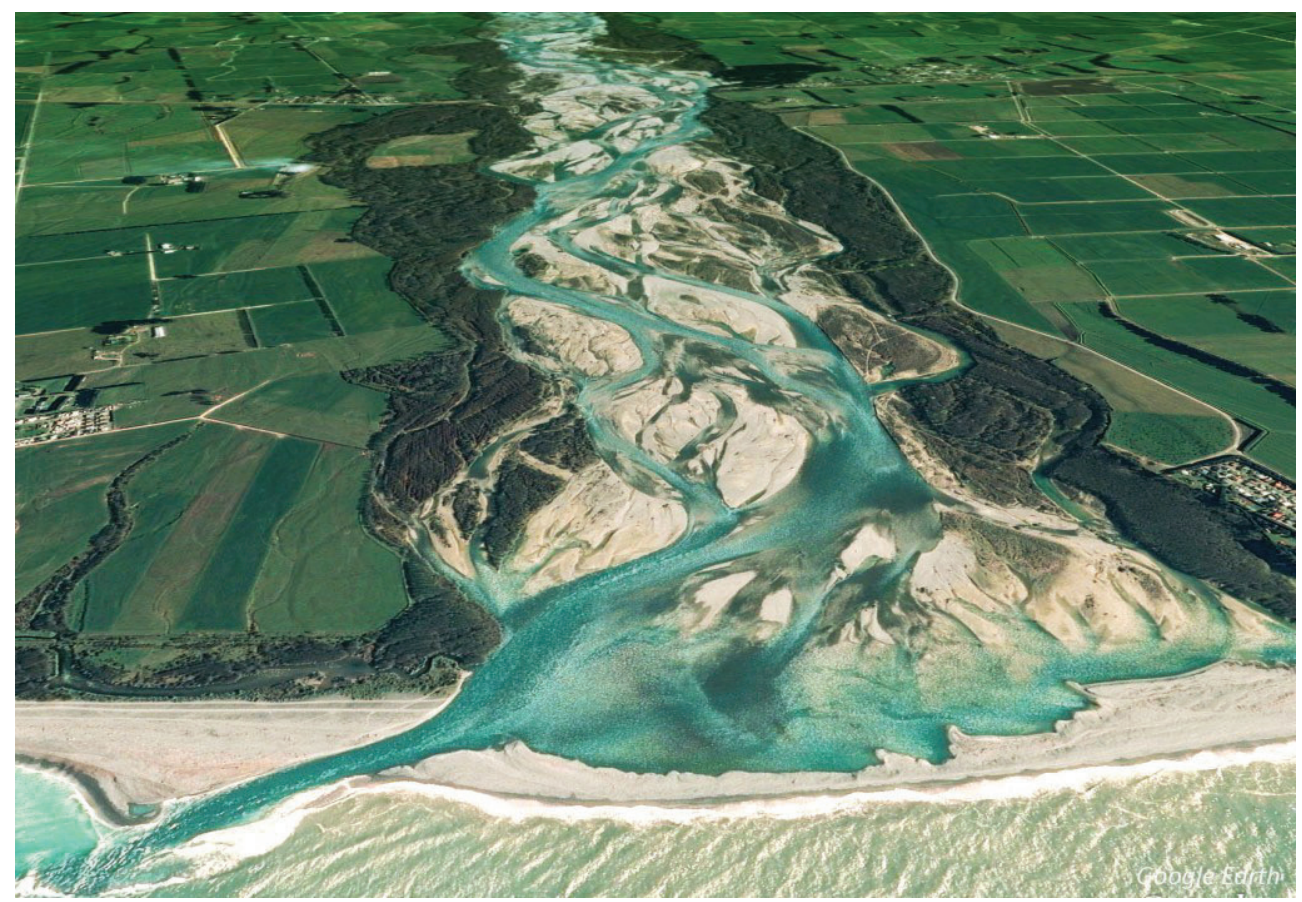

Figure 2. The Waitaki River Mouth. Image from Google Earth sourced per https://braidedrivers.org/rivers/waitaki-lower/

valley below, to his brother Takaroa, deity of the moana on the East Coast. Karaitiana ${ }^{8}$ also recalls a narrative about Aoraki which connects Kirikiri Katata, the ariki (chief) of the Arai-te-uru waka, with the lower summit of Aoraki, to stand where the rakatira reside on the highest peaks of the land.

It is from the whenua, awa, and moana that we reconnect with an innate sense of self, identity, belonging, place and our tipuna that remain named within our landscapes. There is a symbiotic thread between ancestral lands and water, which is profoundly associated with Māori health and well-being. ${ }^{9}$ The Waitaki River was also a significant landmark to Edward Shortland who, accompanied by local chief Huruhuru, was the first European to record his exploration of the Waitaki Valley in January 1844, as noted in his diary about the "furiously rapid and a dirty white colour" of the Waitaki River. ${ }^{10}$ Interestingly, the first official interior map of the Southern Districts of New Zealand has an earlier date by six years.

The kawa and lore of Rākaihautū was taught by our rakatira and prophet Te Maihāroa (? - 1886) in whare wānaka (ancient school of learning) throughout Te Waipounamu. Te Maihāroa lived his life dedicated to this lore, living as a kaitiaki guardian of Papatūānuku (Earth Mother). The writer is a mokopuna of Te Maihāroa. Known as the last tohuka of Te Waipounamu, Te Maihāroa is remembered as a champion for Māori rights and for leading a passive resistance movement through Te Heke (The Migration) 1877-1879 in a bid to retain the ancestral land from the bottom of the eastern foothills of the Southern Alps through to the West Coast as retold and cited in several sources including; Mikaere, 1988; ${ }^{12}$ Riseborough, 1989; ${ }^{13}$ Elsmore, 1999; ${ }^{14}$ Te Maihāroa, 1957; ${ }^{15}$ 


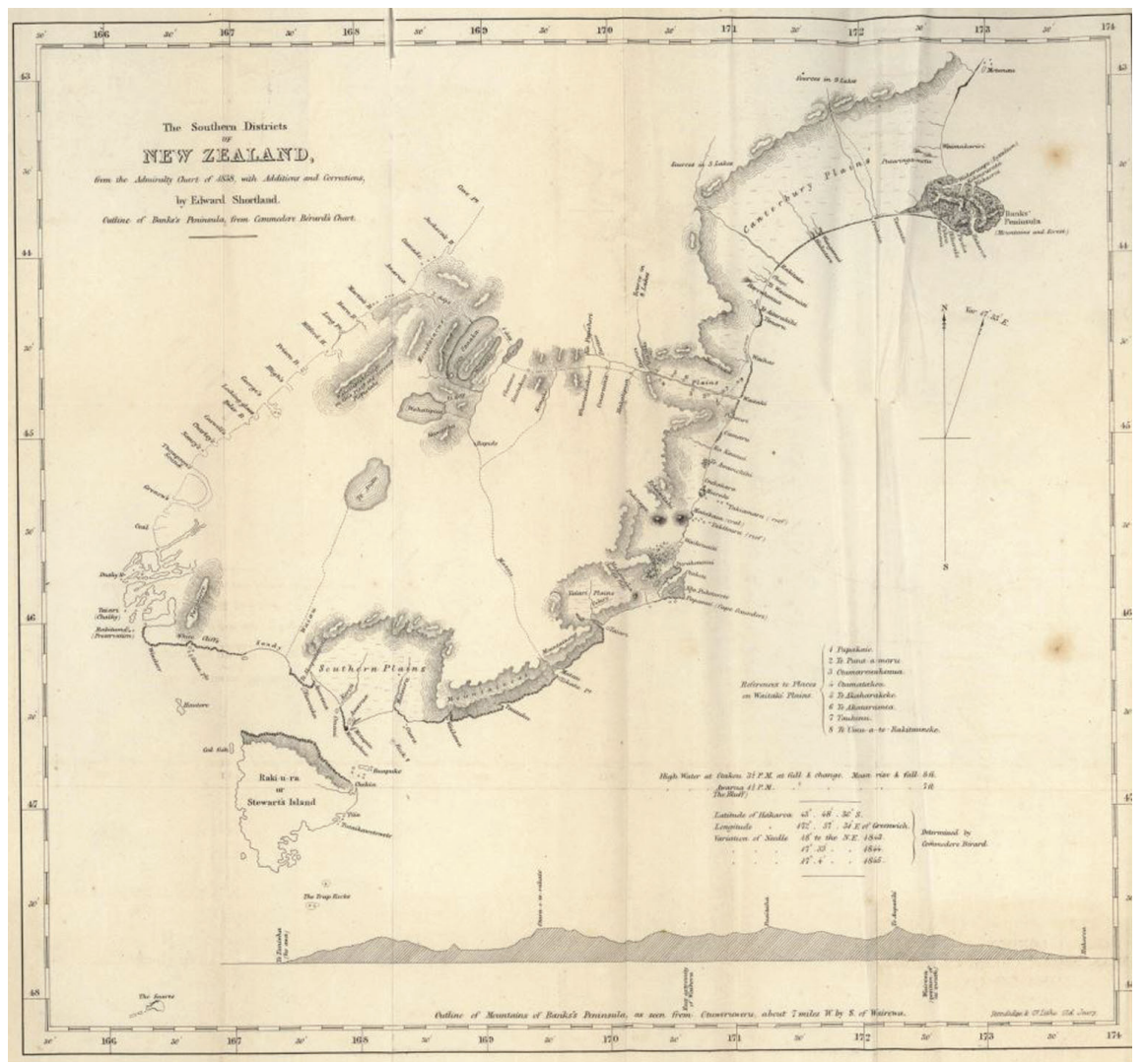

Figure 3. "Map of the Southern Districts of NEW ZEALAND from the Admiralty Chart of 1838. With Additions and Corrections, by Edward Shortland.

Outline of Banks's Peninsula, from Commodore Berard's Chart."11

Beattie Collection, 1939-1945. ${ }^{16}$ Te Maihāroa claimed that the interior of the South Island had not been sold to the Crown and therefore remained Māori land, believing that physical occupation would retain this position. Te Maihāroa led his people through the Waitaki Valley to establish a Māori village at Te Ao Mārama (commonly known today as Ōmārama), but after two years of peaceful living, they were relocated to Korotuaheka, a Māori reserve at the mouth of the Waitaki river. Te Heke (1877-79) represents just one of the injustices played out on the banks of the Waitaki River.

It was the middle of winter. Snow was falling, and it was bitterly cold, With their carts, drays, the small group of Waitaha began the long, painful trek to the mouth of the river, where they still owned a few acres. One can well imagine the feelings of their old chief and tohunga Maiharoa as he passed through the tribal camping ground of Maukatipua and climbed the top of the Otematakou Saddle. The last of the ancient lineage of the chiefs of Waitaha, he looked back, deprived of his birthright, at the lands where for remote ages his people had hunted, fought and died. Slowly he turned his back on those great mountains and valleys, and with a sad heart began the long journey to the coast. ${ }^{17}$ 


\section{WAITAKI: A RIVER OF MANA AND WATER OF TEARS}

The mana of the Waitaki River is upheld by the Waitaha people through political struggles, environmental concerns, and cultural revitalisation. The call to uphold the mauri and mana of this ancestral river is discussed through four contemporary events: two Environmental Court submissions and two cultural commemorative events. The two significant political and environmental events represent the 'water of tears' through the reflection of two unsuccessful Waitaha Environmental Court submissions aimed at protecting the Waitaki River from Meridian Energy hydroelectrical developments: Project Aqua (2001-2004) and the North Bank Tunnel (2005-2009). The two cultural events represent the 'river of mana' through celebrating the Ocean to Alps (1990) national commemoration of the 150th anniversary of the signing of Te Tiriti, and Te Heke Ōmāramataka (2012), a peace march to honour the mauri of the Waitaki River and to remember Te Maihāroa and our Te Heke whānau.

Similarly, to the interdependent life force of the Waitaki River, each of these four events are in many ways intertwined and reliant on the support and prosperity of multiple moving parts in order to achieve human and environmental wellbeing.

\section{Water of Tears: Project Aqua (2001-2005)}

Toku awa, ko toku mana,

Toku awa, ko toku kaha,

Toku awa, ko toku ora,

Toku awa, ko toku wairua,

Toku awa, ko ahau!!

(My river is my authority, my river is my strength,

my river is my life, my river is my spirit,

I am the river, and the river is me.

Ko Waitaki toku Awa!!)

(Anne Te Maihāroa-Dodds). ${ }^{18}$

Anne Te Maihāroa Dodds shared this opening statement at the Project Aqua Waitaki River Low-Flow trial in June 2005. It asserts her mana as the living expression and embodiment of her ancestral whakapapa through her eternal connection with her sacred Waitaki River. As an original member of the Lower Waitaki Zone Committee and a member of the Lower Waitaki River Management Society, Anne Dodds responded when the 2003-4 Waitaki District Council called for submissions to establish the potential minimum flow of the Waitaki River in relations to water use allocation, including the hydro dams of Meridian Energy. Anne and her older brother Rangimārie Te Maihāroa had become increasingly concerned with the diminishing mauri and misuse of this precious taoka (treasure) and ancestral waters. 
When Meridian Energy first put forward the Project Aqua proposal, it was pitched in 2001 as a $\$ 1.2$ billion hydro scheme on the lower Waitaki river. Both Anne and Rangimārie submitted appeals against Project Aqua, concerned about the cultural and environmental impact. In order to highlight these issues and mobilise community concerns, Anne and Rangimārie instigated a peace march to honour the mauri of the Waitaki River. Anne was clear that this would be a

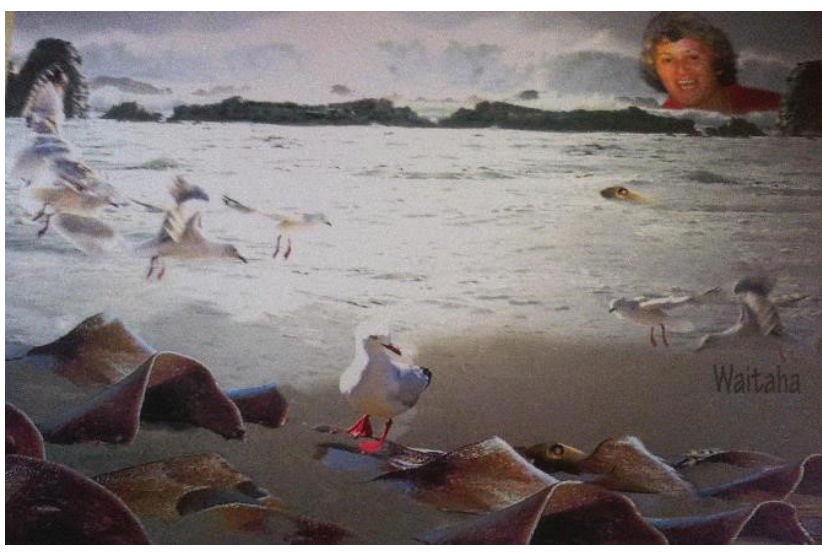

Figure 4. Montage of Anne Sissie Pate Titaha Te Maihāroa-Dodds by Ramonda Te Maihāroa. Private collection Anne Te Maihāroa-Dodds. peaceful protest of protection for the Waitaki river and set a clear kawa that protest banners would not be welcomed. This peaceful march represented protection, rather than a demonstrated protest.

The peace march was a showstopper, with one of the main State Highway 1 lanes being closed by Transit New Zealand on Anne's request. Anne started the event with a karakia, calling together over 800 people from throughout Te Waipounamu, marching in silence as a form of passive resistance against the proposed Project Aqua development. The silent background was the perfect setting for the echoes of pūtātara (conch trumpets) and river stones tapped together to replicate the chattering braids of the Waitaki river. The crowd was led down the closed lane by a dancing masked pouākai (large mythological bird, may refer to the extinct endemic Haast's eagle) and a duet sung by Ramonda Taleni Te Maihāroa and Anna Good. Ōtakou composer Gillian Whitehead wrote an aria entitled 'Waitaki Awa' 19 especially for this occasion, along with many other cultural performances to support the kaupapa.

Anne Te Maihāroa Dodds's plea to Meridian Energy and her community was simple: please do not diminish the mauri of our ancestral awa. This was backed up by her submission to parliament on this issue, as invited by local member of parliament the Honourable David Parker. Meridian's Project Aqua was terminated in 2005 after considerable opposition for this proposed hydro and irrigation development. ${ }^{20}$

\section{WATER OF TEARS: NORTH BANK TUNNEL CONCEPT (2007-2010)}

Despite Meridian's termination of Project Aqua (2001-2005), the opportunity to push forward with another large-scale hydro development on the Waitaki River was launched by Meridian Energy soon after, with the proposed the North Bank Tunnel concept (2007-2010). This hydroelectric scheme projected a $\$ 993$ million spend on a $34 \mathrm{~km}$ tunnel aimed at taking water from Lake Waitaki through a North Bank Tunnel and discharging it back into the Waitaki river. ${ }^{21}$ It was expected to produce an additional 1,100-1,400 gigawatt-hours per annum of power and irrigate the Hunter Downs Irrigation scheme in the process. This moved Anne and her brother Rangimārie to make submissions against Meridian Energy's proposed North Bank Tunnel hydro concept. 
Although there was support for the protective environmental stance of Anne and Rangimārie from throughout Aotearoa, their actions required a lengthy and costly legal opposition in the Environmental Court held in Oamaru, North Otago, that lasted for several weeks. Although Rangimārie and Anne were now both in their seventies, they remained undeterred by the huge challenge that faced them to protect the mauri or their beloved Waitaki River. They won many mitigating conditions and were awarded tangata whenua standing rights in the Environmental court by Judge Jackson. The North Bank Tunnel Scheme was cancelled in 2013.22

\section{RIVER OF MANA: OCEAN TO ALPS 1990}

An important event that represents the significance of the Waitaki River was the commemorative Ocean to Alps journey (1990), which celebrated 150 years since the signing of Te Tiriti between Māori and the British Crown. To honour the Nation's founding legal document, this prestigious occasion within the Waitaki Valley paid homage to the Waitaki River through fifteen community events held throughout the Waitaki Valley towards Aoraki. ${ }^{23}$ Rangimārie Te Maihāroa, (Ūpoko, spiritual head) of the Waitaha Tai Whenua Trust Board), and Margaret Austin were Commissioners for the 1990 Celebrations. Aoraki is sacred to Waitaha, not only as a physical manifestation of Aoraki the ancestor, but also as the connecting spiritual thread between the physical and nonphysical world. As highest peak of Kā Tiritiri o te Moana, the Southern Alps, Waitaha look to this sacred mauka for guidance, inspiration and connection to the spiritual world.

The event began at the Waitaki River mouth on the eve of the New Year, 31st of December 1999, starting with a small mōhiki (reed boat) which carried two chosen kōhatu (stones) to a series of jet boats which returned the kōhatu from the river back to its source of origin at the base of Aoraki (Mt Cook) and Haupapa, (Tasman Glacier). One of the highlights of this festivity was the launch of a large waka taua (carved wooden boat) on Lake Pūkakī, loaned from the Tasman District. Although this event was focused on the celebration of Māori and European partnership, it also provided a national opportunity for Waitaha and southern Māori to highlight the importance of the mighty Waitaki River as a main highway, an abundant food basket, medicine cabinet and a source of great pride and mana.

This national event brought together people from throughout Aotearoa to celebrate this sesquicentennial occasion. It was important for Anne and Rangimārie to focus this event based around the Waitaki Valley based on Māori-Pākehā partnerships. This bicultural perspective acknowledged the importance of the Waitaki River to all people who live, work and play within the Waitaki Valley. Their collective vision for this day provided not only a significant social and cultural event within the Waitaki Valley and along the riverbank, it also provided the opportunity for both Treaty

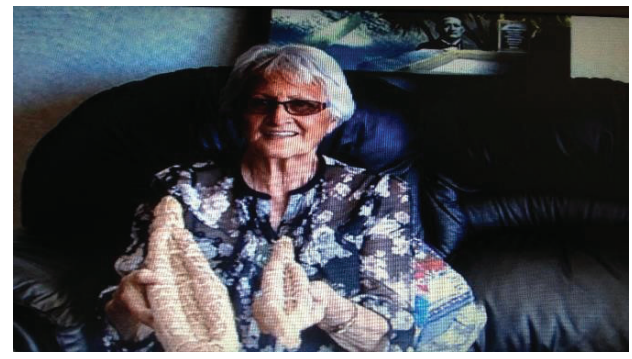

Figure 5. Anne Te Maihāroa Dodds showing her miniature mōkihi. April 2014.

Private collection Anne Te Maihāroa Dodds. 


\section{RIVER OF MANA: TE HEKE ŌMĀRAMATAKA 2012}

At the annual general meeting of Waitaha Tai Whenua Trust Board in April 2012, the whānau mooted the idea to retrace the Te Heke 1877 trail, as it had been 135 years since Te Maihāroa led his people through the valley as a protest against Te Tiriti breeches. The treaty guaranteed that Māori would retain paramount authority over their lands and treasures. The contemporary peace march sought to commemorate the leadership of pōua Te Maihāroa and his people on Te Heke (1877) and highlight the diminishing mauri and environmental effects on the Waitaki River. The Waitaki River was and remains an ancestral treasure, the central bloodline of the Waitaha people. In an effort to record and preserve history, whānau were invited to record their journey in daily journals, which also formed partial fulfilment of the writer's Doctoral Thesis. Quotes from participants' writings in their whānau journals are included in the following paragraphs. ${ }^{24}$

Approximately fifty whānau members joined Te Heke o Ōmāramataka, which comes from the Māori concept Ō mā hā ra ta ngā, derived as the ancient sounds from another nation, in another time, the dream time, the memory time, the time of many suns shining. ${ }^{25}$ The whānau journals documented the experiences of whānau participants as they walked up the Waitaki Valley from 27th - 31st of December 2012. A hue (gourd) was especially created to carry some of the sacred water from the mouth of the Waitaki river back up through the Waitaki Valley

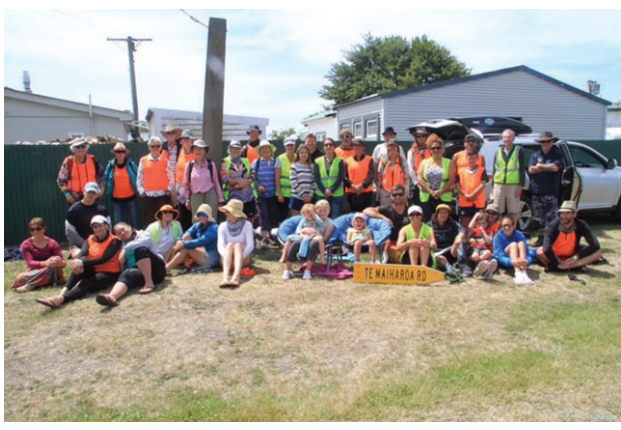

Figure 6. Te Heke ki Korotuaheka 2016. to one of the Waitaki River sources, the Ahuriri River. This small but significant ritual was important to the whānau, as it involved researching and bringing to life a traditional water carrying vessel that has links to te ao tāwhito (the ancient world). One of the whānau journal entries reflects the time and commitment to re-establishing such rituals:

Arrived at the mouth of the Waitaki awa on the afternoon of the 26th of December 2012. Had been very busy for many months prior, making special taonga for this heke. It was great to be here at last. Went and collected water from the river mouth for the hue, used another taha for this purpose (from whānau journal - participant E).

Not surprisingly, the sacredness of the Waitaki River was a reoccurring theme for whānau. Some of this water was used as a star mirror to reflect the majestic night sky and signify this special time. Karakia was infused with the pouring of water into the gourd so that the blessings would accompany the trekkers:

We all bonded as we tried to light the fire the traditional way - over a couple of hours we achieved heat and smoke but did not get a flame, this activity certainly warmed us. We lit the fire on the stony beach the modern way and in the light and warmth of the fire there was karakia and waiata. Whaea said karakia as the water was placed in the vessel to reflect and absorb the starlight (from whānau journal - participant D).

This star ceremony and the purity and sanctity of the Waitaki water is also captured in the kōrero below, where the connections of te ao wairua, the spiritual realm are called to in te reo rakatira, the chiefly Māori language: 
We embark on the star ceremony, and transfer the water of the Waitaki River mouth, which is held in the hue, into the star bowl. The ipu is made from beautiful clay, specially sourced for this ceremony, with the white clay reflecting the stars and the moonlight. The opening ceremony is conducted in te reo Māori. It is ritualistic and haunting. The kōrero speaks about far off places and the names of our tīpuna. The names of the tīpuna on Te Heke have not been captured in entirety (from whānau journal - participant A).

Rituals are important, as they reconnect us with our ancient ways of knowing and being. This whānau member describes the ritual processes undertaken and an awakening of energy that made for a restless night:

The whānau gathered around the ahi tāpu, karakia were said. Next the water from the taha was poured into the ipu for the night stars to dance upon, karakia were woven into the waters followed by waiata. I was very fatigued following the creative build up by this stage and did not sleep well this night. (from whānau journal - participant E).

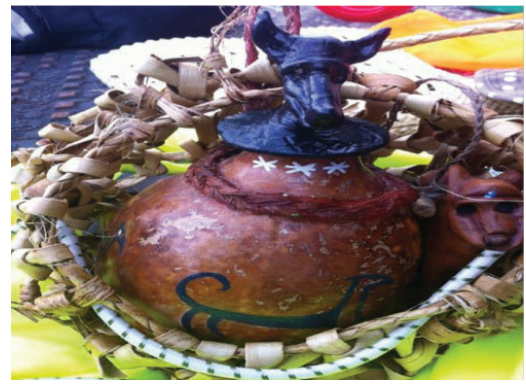

Figure 7. The elaborate hue which carried the sacred Waitaki waters through the Waitaki valley.

Te ao hurihuri, the ever-changing world of evolvement, continued to be a theme for whānau from the first night and throughout the heke. Several whānau mentioned the changes of time and preparation for spiritual change:

There was a lot of pressure towards the end of 2012 with the change in the Mayan calendar from the stone calendar to the water calendar and in my life, there were big changes. I had one hour's sleep and out to the Waitaki River mouth by 5.50 a.m. Good to get there in time for the ceremony. There was a feeling of the unknown as to what was going to happen, and I felt comfortable in being there and had a strong commitment to the task ahead. Beautiful sounds have stayed with me from the opening the start of the journey and the sincere, honest words that were spoken at the ceremony (from whānau journal - participant B).

Morning karakia was held on dawn at the mouth of the Waitaki to offer thanks for this day, and prayers to watch over the rōpū throughout the heke. The importance of reconnecting the water with its source was important for one whānau member: "The fire was lit and stored for the journey, water from the Waitaki Mouth was gathered, to be carried (up) to Omarama and placed in the Ahuriri River to once again mingle and flow back to the Waitaki mouth and the sea" (from whānau journal - participant I). The process of re-creating some of these ancient water rituals prompted another to reflect on this heartfelt journey: "whaea said a karakia as the waters were poured into the hue for the journey, the

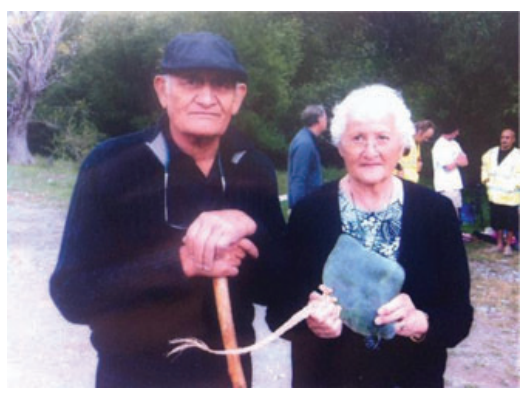

Figure 8. Rangimārie and Anne Te Maihāroa, Ahuriri River. December 2012.

Private collection Anne Te Maihāroa-Dodds. pūkāea sounded, I harnessed the hue next to my heart and the journey began" (from whānau journal - participant D). It was as if the rituals reminded whānau of a different passage of time: 
We had a karakia at the Waitaki Mouth. Whānau got ready the lighting of the fungi that would take the fire from the mouth and finish off in Omarama. Whānau gathered water from the Waitaki Mouth in a gourd. It's at this time I realized that we live in a Pākehā world - our ancestors must have done life very hard. Time was not by a watch on their arm. We spent the night thinking and learning (from whānau journal - participant F).

Karakia were continual throughout this journey, not only to watch over the whānau, but also to ask for forgiveness and blessings for the mana of the Waitaki river and tributaries: “... I carried the water hue, the day started with a good pace and plenty of energy, and we were all in good spirits. We said karakia as we crossed the waters - they look so sad and depleted" (from whānau journal - participant D). The traditional re-created way of transporting the mauri of the Waitaki waters in the hue and the simmering fire embers symbolising ahi kā roa (long burning fires) were not only novel to the whānau, but also of great interest to those passing on the busy summer highway, and it was reported in the Otago Daily Times on the second day of the journey.

There were many challenges on this hikoi, especially the first leg which was 40 kilometres long, as recounted

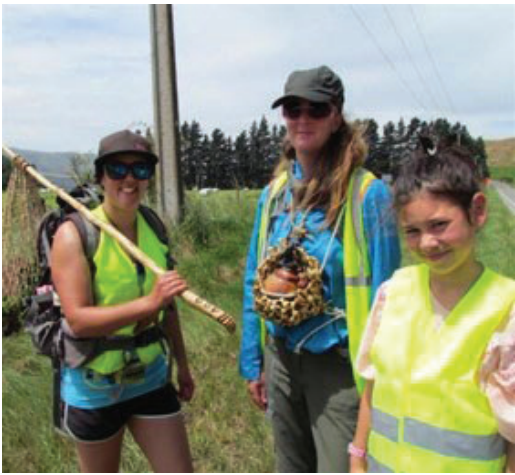

Figure 9. Carrying the sacred waters from the Waitaki River mouth back to the Ahuriru River during a heke to remember their ancestor Te Maihāroa. 28th December 2012.

Photograph: Andrew Ashton.

Courtesy Otago Daily Times. ${ }^{26}$ by one participant: "I tautoko the water and fire walkers all the way both in Te Ao Tangata me Te Ao Wairua. There were many challenges managing both these elements" (from whānau journal participant E). Transporting the earthly elements of water and fire, in the memory of Te Maihāroa, synthesised the connection between whānau and with the whenua:

I'm really recognising what a special pilgrimage / journey that we are all on - the carrying of the waters and the fire: the wind helping to move us along the way (the winds of change?) and the connection of feet to earth and treading softly - reconnecting to our earth mother - was so profound (from whānau journal - participant C).

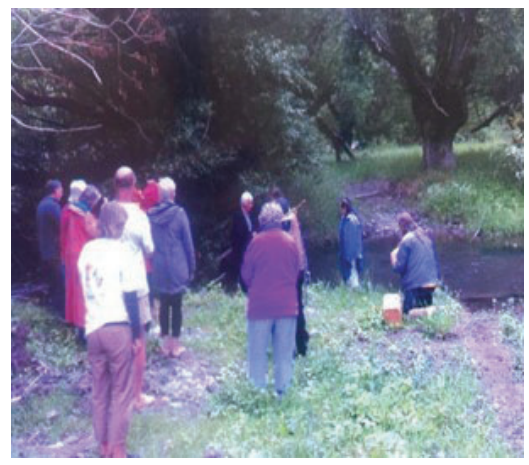

Figure 10. The end of the closing ceremony, where the water carried from the mouth of the Waitaki River was returned to the Ahuriri Stream, Ōmārama. 30th December 2012. Personal whānau collection. 


\section{WATERS AS EMBODIMENT FOR WAITAHA}

This paper began with the ritual chant by Rākaihautū, which separated the mighty Pacific Ocean to create a safe passage for the Uruao waka to Aotearoa. Water was found in abundance within this southern landscape, and the significance of this is recorded through Rākaiahautū feats as he consecrated the whenua and named the pools of water that would sustain life for Waitaha. During these ancient times of creation, Aoraki and his brothers were immortalised, with their symbolised tears flowing out to sea through the braided tear streams of the Waitaki River. Aoraki and the Waitaki River remain an embodiment of Waitaha ancestors since immortal times, and a central tribal identity for Waitaha. The second half of this article outlined several political and environmental events aimed at restoring the mauri of the river. The term 'river of mana and water of tears' relates to four events based on upholding the mana of the Waitaki River as a taoka. Waitaha leaders, Rangimārie Te Maihāroa and Anne Te Maihāroa Dodds and Rangimārie were expert witnesses in two submissions against Meridian Energy's proposed hydro-electrical projects: Project Aqua (2001-2005) and the North Bank Tunnel (2007-2010); both of these ventures were subsequently terminated. The cultural commemorations such as Ocean to Alps (1990) and Te Heke ki Ōmāramataka (2012) celebrated the special relationship between the river, those that live in the Waitaki Valley and the unique spiritual and cultural significance to Waitaha whānau today. The Waitaki River remains an ancestral treasure, as a lifeline connecting an ancient past through to an uncertain braided future. As kaitiaki (guardians) of the Waitaki River, there is a duty of care to uphold her mauri, or the spiritual essence of her diverse ecosystems, so that she continues to flourish for our mokopuna (grandchildren) of the future.

Waitaki River: Water of Tears, River of Mana

Ko awa ko au, ko koe ko awa

The river is me and I am the river

Kelli Te Maihāroa (Waitaha, Ngāti Rārua Ātiawa)

Ko Aoraki rāua ko Taranaki kā mauka teitei

Ko Waitaki rāua ko Waitaha kā awa

Ko Waitaha rātou ko Ngāti Rārua Ātiawa kā iwi

Ko Kelli Te Maihāroa tōku ikoa

\author{
Aoraki and Taranaki are the ancestral mountains \\ Waitaki and Waitaha are the ancestral rivers \\ Waitaha, Ngāti Rārua \& Te Ātiawa are the tribes \\ Kelli Te Maihāroa is my name
}

Dr Kelli Te Maihāroa has an extensive background in education and social services, with a focus on bi-cultural responsiveness and kaupapa Māori initiatives. She sees education as the number one lever to address equity issues and the potential to transform peoples' lives. At Otago Polytechnic Kelli holds two leadership roles as Tumuaki: Rakahau Māori | Director: Māori Research and Kaihautū: Te Kāhui Whetū: Capable Māori, working with Iwi Māori throughout Aotearoa New Zealand. She is an active member within her whānau, hapū, Iwi and local Māori community. Kelli is a mokopuna of Te Maihāroa, the last southern Māori prophet and tohuka (expert tribal specialist). Her area of research interest is Indigenous peace traditions, Indigenous research, cultural revitalisation and Māori educational initiatives. Kelli was a co-editor for an edited collection: $\mathrm{H}$. Devere, K. Te Maihāroa, \& J.P. Synott (eds.) Peacebuilding and the Rights of Indigenous Peoples: Experiences and Strategies for the 21st Century, (Springer: Cham, Switzerland, 2016). 
1. Herries Beattie, "The Heke to Omarama 1878: A Celebrated Migration Which Nearly Led to Fighting," in Beattie Collection, Hocken Collections Library. New Zealand: University of Otago, 19391945, E-21, 1-19.

2. Simon Bloomberg, "Waitaki: Water of Tears, River of Power," New Zealand Geographic, 51, May-Jun 2001, https://www.nzgeo.com/stories/waitakiwater-of-tears-river-of-power/ Accessed 8 May.

3. Kelli Te Maihāroa, "Kā Pākihi Kā Whakatekateka a Waitaha / The Plains Where the Waitaha Strutted Proudly," Thesis submitted for the degree of Doctor of Philosophy at the University of Otago Te Whare Wānaka o Otago Dunedin, Aotearoa New Zealand, September, 2019

4. Herries Beattie, "Traditions and Legends: Collected from the Natives of Murihiku (Southland New Zealand)." The Journal of the Polynesian Society, 27, no. 107, 137-161. http://www.jps.auckland.ac.nz/document// Volume_27_1918/Volume_27\%2C_No._107/ Traditions_and_legends._Collected_from_the natives_of_Murihiku._\%28Southland\%2C_New_ Zealand\%29\%2C_by_H._Beattie\%2C_p_146 Accessed 8 May.

5. Land Information New Zealand Toitū Te Whenua (LINZ), https://gazetteer.linz.govt.nz/

6. Ibid., See the telling of the place names of the ancestors in "Rākaihautū - Naming great lakes of the canoe of Aoraki". See also the place names and translations drawn from the text at the same page at “A Tale from He Korero Pūrākau Mo Ngā Taunahanahatanga a Ngā Tūpuna (Place Names Of The Ancestors) - A Māori Oral History Atlas. https://www.linz.govt.nz/regulatory/placenames/about-new-zealand-geographic-board/ nzgb-place-name-maps-and-publications/ he-korero-p \% C $5 \%$ A B r \% C 4 \% 81 ka u-mong\%C4\%81-taunahanahatanga-ng\%C4\%81t\% C5\%ABpuna/r\%C4\%81kaihaut\%C5\%ABnaming-great-lakes-canoe Accessed 8 May.

7. Nick Karaitiana, "History of a Great River," Te Ao Hou/The New World 52, (September 1965) 50-53 http://teaohou.natlib.govt.nz/journals/teaohou/ issue/Mao52TeA/c18.html Accessed 8 May

8. Ibid.

9. Wendy Henwood and Remana Henwood, "Mana Whenua Kaitiakitanga in Action: Restoring the Mauri of Lake Ōmāpere," AlterNative: An International Journal of Indigenous Peoples 7, no. 3 (December 2011) 220-232.
10. Edward Shortland, The Southern Districts of New Zealand; A Journal with Passing Notices of the Customs of The Aborigines, (Longman, Brown, Green \& Longmans: London, 1851) 198.

11. Ibid. ii (front pages).

12. Buddy Mikaere, Te Maiharoa and the Promised Land (Heinemann: Auckland, New Zealand, 1988).

13. Hazel Riseborough, Days of Darkness: The Government and Parihaka, Taranaki 1878-1884 (Penguin Press: Auckland, 1989).

14. Bronwyn Elsmore, Mana from Heaven: A Century of Māori Prophets in New Zealand, (Raupo Publishing: Auckland, 1999).

15. Taare Te Maiharoa, Folklore and fairy tales of the Canterbury Māoris / told by Taare te Maiharoa to Maud Goodenough Hayter (Mrs. T. Moses); edited by Herries Beattie (Dunedin, 1957).

16. Beattie, Traditions and Legends.

17. Karaitiana, 53.

18. Anne Te Maihāroa-Dodds, "Additional Evidence on Project Aqua - Waitaki River Low-Flow Trial." Te Kaharoa 10, (2017) June 2005, ISSN 1178-6035.

19. Gillian Whitehead, Te Mauri o te Awa, https://www. gillianwhitehead.co.nz/music/solo-voice.html

20. “2004: Meridian's Project Aqua Terminated”, Otago Daily Times, 2 February 2012. https:// www.odt.co.nz/2004-meridians-project-aquaterminated (accessed June 8, 2020).

21. David Bruce, "Decision Expected Soon on North Bank Tunnel," Otago Daily Times, August 8, 2008. https://www.odt.co.nz/regions/north-otago/ decision-expected-soon-north-bank-tunnel

22. Jacquie Webby, "Meridian suspends land negotiations," Oamaru Mail, January 20, 2013. http://www.oamarumail.co.nz/news/merdidiansuspends-land-negotiations/17238 (accessed June 8, 2020).

23. Kelli Te Maihāroa, Te Ara ō Rakimārie: The Pathway of Peaceful Living, Te Kaharoa (2017) 8, Timaru Herald, 1 December 1990.https://www. tekaharoa.com/index.php/tekaharoa/article/ download/151/141/

24. Kelli Te Maihāroa, Thesis (2019).

25. Rua Pick, personal communication to author, July 7, 2016.

26. "Ancestral Journey Retraced," Otago Daily Times, 2 January 2013. 